\title{
Korelasi Tingkat Kepatuhan Konsumsi Obat Antiepilepsi Menggunakan Kuesioner MGLS (Morisky, Green, Levine Adherence Scale) dengan Frekwensi Kejang Pasien Epilepsi
}

\author{
Iin Ernawati ${ }^{1}$ and Wardah Rahmatul Islamiyah ${ }^{2}$ \\ ${ }^{1}$ Akademi Farmasi Surabaya, Ketintang Madya No. 81, Surabaya, Jawa Timur, Indonesia 60231 \\ ${ }^{2}$ Spesialis Syaraf, Departemen Saraf, Fakultas Kedokteran Universitas Airlangga, Surabaya, Indonesia
}

Reception date of the manuscript: 14 Juni 2020

Acceptance date of the manuscript: 14 Agustus 2021

Publication date: 31 Desember 2021

\begin{abstract}
Epilepsy is a chronic non-communicable brain disorder that can affect people of all ages. AED (antiepileptic drug) is the main therapy for most epilepsy patients with the overall goal being to prevent seizures without causing side effects. One measure of management of drug therapy in epilepsy is the decrease / loss of seizures, so that the frequency of seizures is one of the measures to achieve endoutcome. This study was an observational cross sectional study conducted on outpatients in Airlangga University Hospital, which aims to look at the relationship between the level of adherence using antiepileptic drugs with the incidence of seizures in epilepsy patients. The level of adherence with AED consumption in this study used the MGLS questionnaire (Morisky, Green, Levine Adherence Scale). The level of adherence based on the MGLS questionnaire was divided into 3 levels including low, medium or high adherence. The seizure events in epilepsy patients observed were the presence or absence of seizures during the past month, the data of which were obtained from patient or family interviews and from diary seizures. The results of the study of 40 respondents found that there was a moderate positive correlation between the level of adherence measured using the MGLS questionnaire whose majority level of adherence was moderate with the occurrence of seizures in epilepsy patients $(r=0.423$ with $\mathrm{p}=0.006<0.05$.
\end{abstract}

Keywords-epilepsy, adherence, antiepileptic drugs, seizures, MGLS

\begin{abstract}
Abstrak-Epilepsi merupakan penyakit gangguan kronis pada otak yang tidak menular yang dapat mempengaruhi orang dari segala usia. OAE (obat antiepilepsi) merupakan terapi utama kebanyakan pasien epilepsi dengan tujuan keseluruhan adalah secara menyeluruh untuk mencegah terjadinya kejang tanpa menyebabkan efek samping. Salah satu ukuran manajemen terapi obat pada penyakit epilepsi adalah menurunnya/hilangnya kejang, sehingga frekwensi kejang menjadi salah satu ukuran pencapaian end outcome. Penelitian ini merupakan penelitian observasional cross sectional yang dilakukan pada pasien epilepsi rawat jalan poli syaraf Rumah Sakit Universitas Airlangga, yang bertujuan untuk melihat hubungan antara tingkat kepatuhan menggunakan obat antiepilepsi dengan kejadian kejang pada pasien epilepsi. Tingkat kepatuhan konsumsi OAE pada penelitian ini menggunakan kuesioner MGLS (Morisky, Green, Levine adherence Scale). Tingkat kepatuhan berdasarkan kuesioner MGLS dibagi menjadi 3 tingkatan diantaranya patuh rendah, menengah atau sedang dan patuh tinggi. Kejadian kejang pada pasien epilepsi yang diamati adalah ada atau tidaknya kejang selama sebulan terakhir, yang datanya diperoleh dari wawancara pasien atau keluarganya serta dari diary seizure. Hasil penelitian dari 40 responden diketahui terdapat korelasi positif sedang antara tingkat kepatuhan yang diukur menggunakan kuesioner MGLS yang mayoritas patuh sedang dengan adanya kejadian kejang pada pasien epilepsi $(r=0,423$ dengan nilai $p=0,006<0,05)$.
\end{abstract}

Kata Kunci-epilepsi, kepatuhan, obat antiepilepsi, kejang

\section{Pendahuluan}

Epilepsi adalah gangguan kronis pada otak yang tidak menular yang dapat mempengaruhi orang dari segala usia (Farruk et al., 2018; Novianae and Sumarno, 2020). Prevalensi epilepsi di dunia sekitar 4 sampai 10 orang per 1000 penduduk (WHO, 2019). Gejala yang paling umum dari epilepsi

Penulis koresponden: Iin Ernawati, iinernawati.apt@gmail.com adalah seizure (kejang). Seizure dapat didefinisikan sebagai suatu gejala klinis yang dikarenakan aktivitas neuronal otak yang abnormal, eksesif dan tidak seimbang. Epilepsi merupakan kondisi unprovoked seizure, sedangkan status epileptikus adalah aktivitas Seizure yang tidak membaik secara spontan atau Seizure yang berulang tanpa adanya perbaikan diantara Seizure yang terjadi (Leach dan Davenport, 2014; Aminoff dan Douglas, 2017). Pengobatan pada pasien epilepsi biasanya menggunakan obat antiepilepsi (OAE).

OAE (obat antiepilepsi) merupakan terapi utama untuk ke- 
banyakan pasien epilepsi dengan tujuan keseluruhan secara menyeluruh untuk mencegah terjadinya kejang tanpa menyebabkan efek samping, lebih diutamakan monoterapi dengan jadwal minum obat yang mudah untuk diikuti pasien. Penelitian terbaru pada negara berpendapatan rendah dan menengah menunjukkan bahwa sebanyak $70 \%$ anak-anak dan dewasa dengan epilepsi berhasil diterapi sehingga kejang terkontrol dengan obat antiepilepsi. Hal ini berlanjut setelah dua hingga lima tahun terapi dan berhasil dan berada dalam keadaan bebas kejang, OAE dapat dihentikan pada sekitar 70\% anak-anak dan $60 \%$ dewasa tanpa adanya relaps atau kekambuhan (WHO, 2017).

Salah satu ukuran manajemen terapi obat pada penyakit epilepsi adalah menurunnya/hilangnya kejang, sehingga perhitungan frekwensi kejang menjadi salah satu ukuran pencapaian end outcome. Frekwensi dan durasi kejang dapat dipengaruhi oleh kadar obat dalam darah (Widyati et al., 2013). Terapi fenitoin pada pasien epilepsi tergantung pada kerja sama dan kepatuhan (adherence) dari pasien. Berdasarkan penelitian Leppik (1997), diketahui kepatuhan pasien yang buruk dan tingkat kadar serum yang rendah dari OAE pada 20-50\% pasien dengan epilepsi. Penelitian lain menunjukkan bahwa $20 \%$ pasien dengan kadar serum level fenitoin yang rendah memiliki tingkat kejang berulang yang lebih banyak yakni 2 kali tiap bulan dibanding dengan pasien lain yang kadar serumnya lebih tinggi dan lebih jarang mengalami kejang (Rasheva et al., 2015).

Kepatuhan yang baik dari pasien diharapkan dapat mempertahankan kadar fenitoin dalam darah sehingga kejadian kegagalan terapi dapat dihindarkan. Kepatuhan pasien dalam mengikuti terapi obat yang diberikan, meliputi kepatuhan jadwal minum dan cara penggunaan obat. Untuk meningkatkan kepatuhan konsumsi obat pasien dapat dilakukan dengan intervensi perilaku dan edukasi (Al Aqeel et al., 2017). Salah satu hal yang masih menjadi tantangan dan menjadi penyebab belum terkontrolnya terapi dengan OAE adalah adherence/ kepatuhan (Widyati, et al., 2013). Hovinga et al. (2008), menemukan bahwa ketidakpatuhan menyumbang $29 \%$ terhadap kontrol kejang. Hal ini terjadi karena terdapat berbagai macam faktor yang dapat memicu kejang dan ketidakpatuhan adalah salah satunya.

\section{BAHAN DAN METODE}

\subsection{Bahan}

Penelitian tingkat kepatuhan ini merupakan penelitian observasional cross sectional yang dilakukan secara prospektif yang sesuai dengan kriteria inklusi dan eklusi. Subjek penelitian pada penelitian ini adalah pasien epilepsi yang menggunakan obat anti epilepsi.

Kriteria Inklusi:

1. Pasien Epilepsi dengan usia dewasa (20-60 tahun)

2. Pasien Epilepsi yang mendapatkan OAE minimal telah mengkonsumsi obat anti epilepsi 1 bulan sebelumnya

3. Pasien atau keluarga pasien yang bersedia ikut dalam penelitian

4. Pasien dengan data tidak lengkap

Kriteria Eklusi:

1. Pasien epilepsi hamil dan anak- anak

2. Pasien epilepsi atau keluarga pasien yang mengalami gangguan mental

Instrumen yang digunakan pada penelitian ini adalah rekam
TABEL 1: KARAKTERISTIK PASIEN

\begin{tabular}{lll}
\hline Karakteristik & $\begin{array}{l}\text { Jumlah } \\
(\mathrm{N} \text { total= 40) }\end{array}$ & Persentase $(\%)$ \\
\hline Usia & 22 & 55 \\
$20-30$ & 6 & 15 \\
$31-40$ & 7 & 17,5 \\
$41-50$ & 4 & 10 \\
$51-60$ & & \\
Jenis Kelamin & 22 & 55 \\
Laki-laki & 18 & 45 \\
Perempuan & & \\
Tingkat Pendidikan & 4 & 10 \\
SD & 8 & 20 \\
SLTP & 22 & 55 \\
SMA & 6 & 15 \\
Perguruan Tinggi & & \\
Terapi OAE & 30 & 75 \\
Monoterapi & 10 & 25 \\
Politerapi & & \\
Lama Konsumsi OAE & & 12,5 \\
<1 tahun & 5 & 52,5 \\
1-5 tahun & 21 & 35 \\
$>$ 5 tahun & 14 &
\end{tabular}

medis pasien dan hasil kuesioner kepatuhan MGLS (Morisky, Green, Levine adherence Scale).

\subsection{Metode}

Pengukuran tingkat kepatuhan konsumsi OAE pada pasien epilepsi pada penelitian ini dilakukan menggunakan kuesioner MGLS. Pasien yang sesuai kriteria inklusi dan eklusi yang telah menyetujui untuk menjadi responden penelitian, diberikan kuesioner MGLS yang telah alih bahasakan ke bahasa Indonesia dan di uji validasi dan reliabilitas sebelumnya. Frekwensi kejang/Seizure pasien diperoleh dari data wawancara dengan pasien atau keluarga pasien dan melihat dari data diary Seizure yang dimiliki pasien. Frekwensi kejang pasien yang diamati adalah jumlah kejang yang terjadi dalam sebulan terakhir. Penelitian ini dilakukan di Poli Saraf Rumah Sakit Universitas Airlangga pada bulan Mei-Juni 2018. Penelitian ini telah mendapatkan layak etik dari Komite Etik RS Universitas Airlangga dengan Nomor layak etik 143//KEH/ 2018.

\section{HASIL}

Berdasarkan data profil demografi subjek penelitian (Tabel 1) diketahui bahwa terdapat pasien laki-laki sebanyak $55 \%$ dan perempuan $45 \%$, dengan rentang usia paling banyak usia 20-30 tahun (55\%). Tingkat pendidikan terbanyak adalah Sekolah Menengah Atas (SMA) atau yang setara sebanyak $55 \%$. Lama terapi penggunaan OAE untuk rentang 15 tahun sebanyak 52,5\% sedangkan yang lebih dari $>5$ tahun sebanyak $35 \%$. Pola peresepan pada pasien mayoritas monoterapi OAE sebanyak $75 \%$.

Korelasi/hubungan antara tingkat kepatuhan menggunakan kuesioner MGLS (rendah, sedang atau menengah dan tinggi) dengan kejadian kejang (Gambar 1), pada penelitian ini menggunakan uji statistik Spearman dengan menganalisa statistik ketiga kategori tingkat kepatuhan (berdasarkan skor MGLS) dengan kategori kejadian kejang (ada atau tidak adanya kejang selama 1 bulan terakhir). Persentase frek- 
wensi kejang pada penelitian ini dapat dilihat di Tabel 2. Berdasarkan uji statistik korelasi Spearman antara kategori tingkat kepatuhan menggunakan kuesioner MGLS dan timbulnya kejang didapatkan nilai $\mathrm{r}=0,423$ dengan nilai $\mathrm{p}=$ $0,006<0,05$ (signifikan secara statistik). Hal ini menunjukkan adanya hubungan/korelasi sedang antara tingkat kepatuhan dengan adanya kejadian kejang/Seizure.

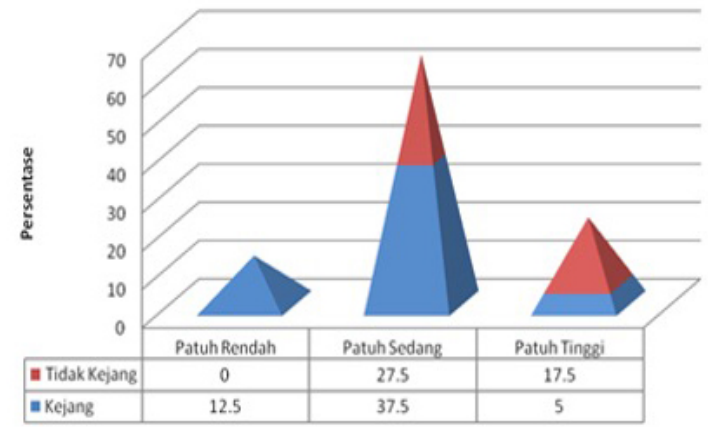

Gambar. 1: Profil Tingkat kepatuhan konsumsi OAE

TABEL 2: PROFIL TINGKAT KEPATUHAN PASIEN MENGGUANAKAN OAE MENGGUNAKAN KUESIONER MGLS DAN FREKWENSI KEJANG PASIEN

\begin{tabular}{lcc}
\hline \multicolumn{1}{c}{ Profil } & $\begin{array}{c}\text { Jumlah } \\
(\mathrm{N})\end{array}$ & $\begin{array}{c}\text { Persentase } \\
(\%)\end{array}$ \\
\hline Tingkat kepatuhan pasien & & \\
konsumsi OAE (skor MGLS) & & \\
Patuh rendah (skor 3 atau 4) & 5 & 12,5 \\
Patuh sedang (skor 1 atau 2) & 26 & 65 \\
Patuh Tinggi ( skor 0) & 9 & 22,5 \\
\hline $\begin{array}{l}\text { Frekwensi Kejang } \\
\text { Tidak kejang dalam } \\
\text { sebulan terakhir }\end{array}$ & 20 & 50 \\
$\begin{array}{l}\text { Ada kejang dalam } \\
\text { sebulan terakhir }\end{array}$ & 20 & 50 \\
\hline
\end{tabular}

\section{Pembahasan}

Penelitian ini merupakan penelitian observasional cross sectional yang dilakukan pada pasien rawat jalan Poli Syaraf Rumah Sakit Universitas Airlangga. Pengamatan pada penelitian ini adalah mengamati korelasi atau hubungan antara tingkat kepatuhan pasien konsumsi obat anti epilepsi dengan munculnya kejang atau Seizure. Tingkat kepatuhan pada penelitian ini menggunakan metode self reported measurement (indirect methode), yakni metode tidak langsung menggunakan kuesioner. Kuesioner yang digunakan adalah kuesioner MGLS (Morisky, Green, Levine adherence Scale) yang telah mendapatkan ijin dari penulis aslinya Morisky et al. (1986) untuk dialih bahasakan ke bahasa Indonesia dan telah di uji validasi dan reliabilitasnya, dengan nilai uji validitas $r$ uji masing-masing pertanyaan berkisar antara 0,596-0,784, dengan nilai $r$ uji lebih besar dari $r$ tabel (0,3496). Alpha cronbach coefficient uji reliabilitas kuesioner sebesar 0,634 $(>0,6)$ (Ernawati and Islamiyah, 2019). Berdasarkan hasil validitas dan reliabilitas dari kuesioner MGLS versi bahasa Indonesia, menunjukkan bahwa kuesioner MGLS reliabel untuk digunakan pengukuran tingkat kepatuhan, sehingga da- pat digunakan untuk mengukur tingkat kepatuhan pada penelitian ini. Kuesioner yang valid dan reliabel diperlukan untuk menjamin data pada pengukuran kepatuhan atau mempresentasikan maksud dari setiap pertanyaan dari kuesioner dan reliabel/dapat digunakan pada penelitian (Ernawati dan Islamiyah, 2019).

MGLS merupakan kuesioner kepatuhan yang dapat mengukur tingkat kepatuhan menjadi tiga tingkat kepatuhan yakni patuh rendah, menengah dan tinggi (Morisky et al., 1986; Beyhaghi et al., 2016; Al Qarni et al., 2019; Ernawati dan Islamiyah, 2019). Tingkat kepatuhan menggunakan kuesioner MGLS dibagi menjadi 3 tingkat kepatuhan yakni tingkat kepatuhan rendah, menengah dan tinggi (Morisky et al., 1986). Berdasarkan hasil penelitian ini diketahui, persentase tingkat kepatuhan rendah adalah $12,5 \%$, untuk yang kepatuhan menengah atau sedang sebesar $65 \%$, dan patuh tinggi sebanyak $22,5 \%$. Frekwensi kejang diketahui bahwa pasien epilepsi dengan tidak muncul kejang selama 1 bulan terakhir sebanyak $50 \%$, sedangkan pasien dengan kejang selama 1 bulan terakhir sebanyak $50 \%$ (Gambar 1).

Penelitian ini sejalan dengan penelitian lain namun menggunakan kuesioner berbeda yakni penelitian melihat tingkat kepatuhan (menggunakan kuesioner MMAS) pasien rawat jalan epilepsi dewasa, diketahui bahwa kepatuhan penggunaan obat mempengaruhi frekwensi kejang, semakin tidak patuh menggunakan obat dapat meningkatkan frekwensi kejang (Gabr dan Sham, 2014). Pada Gambar 1, dapat dilihat ada beberapa pasien yang masih mengalami kejang walaupun kepatuhan tinggi maupun sedang. Hal ini terjadi karena kepatuhan konsumsi obat adalah salah satu unsur keberhasilan terapi pada pasien epilepsi. Jenis epilepsi, faktor etiologi kejang dan kondisi pasien dapat mempengaruhi timbulnya kejang. Kegagalan dalam kontrol kejang sangat dipengaruhi oleh faktor seperti etiologi epilepsi, tipe kejang, ada atau tidaknya komorbid, dan ketidakpatuhan dalam pengobatan (Manjunath et al., 2009; Ferrari et al., 2013). Seizure/kejang terjadi karena adanya letupan listrik yang tidak normal di sel saraf. Faktor pencetus kejang seperti kurang tidur, tidak minum obat pada pasien epilepsi yang mendapatkan terapi OAE, alkohol, obat-obatan terlarang, kelelahan fisik dan mental, adanya gangguan metabolisme dan adanya infeksi (Leach dan Davenport, 2014). Faktor pemicu tersebut dapat menjadi penyebab munculnya kejang meskipun pasien patuh minum obat. Penelitian menyebutkan bahwa kejadian kejang dipengaruhi oleh beberapa faktor diantaranya trauma, masalah psikis (depresi, kecemasan, penurunan kualitas hidup) dan fraktur (Ferrari, et al., 2013). Penelitian oleh Jones et al. (2006) diketahui bahwa ada korelasi negatif antara kepatuhan dengan frekwensi kejang pada pasien yang mempunyai kecemasan tinggi dan kepercayaan rendah terhadap pengobatan. Penelitian lain oleh Shallcross et al. (2015), diketahui bahwa ketidakpatuhan dalam menggunakan OAE memiliki korelasi positif dan signifikan terhadap depresi dengan nilai koefisien korelasi $\mathrm{r}=0,376$.

Kepatuhan adalah ketaatan terhadap terapi obat atau diet atau pola hidup yang diberikan sesuai arahan klinisi/tenaga kesehatan atau dokter (WHO, 2020). Keberhasilan suatu pengobatan tidak hanya dipengaruhi oleh kualitas pelayanan kesehatan dan sikap serta keterampilan petugasnya, tetapi dipengaruhi pula oleh perilaku pasien terhadap pengobatan (Suryani et al., 2013). Berdasarkan WHO (World Health Or- 
ganization) diketahui bahwa pemberian intervensi untuk meningkatkan kepatuhan dapat memiliki dampak yang besar pada kesehatan penduduk daripada perbaikan dalam perawatan medis (Sabaté, 2003). Ketaatan konsumsi minum obat pada pasien epilepsi sangat penting untuk mencegah kejadian kejang dan mengurangi dampak negatif dari kejang pada kehidupan sehari-hari (Dash et al., 2015). Obat antiepilepsi merupakan terapi utama untuk mencegah kejang, dan rata-rata $67 \%$ pasien dengan epilepsi dapat turun frekwensi kejangnya dengan menggunakan obat antiepilepsi (Elger dan Schmidt, 2008). Kepatuhan konsumsi OAE pada pasien epilepsi dapat dipengaruhi oleh beberapa faktor, diantaranya faktor pada pasien seperti usia dan jenis kelamin, kepercayaan pada pengobatan, depresi dan kecemasan, manajemen pengobatan, faktor penyakit pasien, faktor tenaga kesehatan, dan sosioekonomi (O'Rourke dan Buren, 2017; Ernawati et al., 2018; Islamiyah et al., 2019). Pengukuran kepatuhan pada penelitian ini menggunakan kuesioner. Kuesioner merupakan salah satu metode tidak langsung yang memiliki beberapa keuntungan dan kerugian. Kelebihan metode wawancara atau kuesioner diantaranya biaya rendah, tidak invasif dan dapat beradaptasi dengan populasi namun metode kuesioner dapat memiliki kekurangan diantaranya, ada kecenderungan untuk memberi respon yang diinginkan dan sangat individual (Paschal et al., 2008; Ernawati et al., 2018).

Pada penelitian ini diketahui bahwa ketidakpatuhan pasien terhadap pengobatan dapat disebabkan mayoritas karena faktor lupa minum obat (tidak minum) (dari pertanyaan kuesioner MGLS) yang menunjukkan mayoritas pasien pernah mengalami lupa minum obat saat konsumsi obat antiepilepsi. Hal ini sangat erat hubungannya dengan sifat atau karakteristik penyakit epilepsi yakni penyakit saraf yang dapat mempengaruhi kemampuan kognitif dan daya ingat pasien. Epilepsi dapat menyebabkan gangguan daya ingat yang terjadi akibat epilepsi itu sendiri seperti faktor usia saat menderita epilepsi (onset), frekuensi bangkitan, lama bangkitan, tipe epilepsi dan etologi epilepsi (Desai, 2008). Adanya pengaruh penyakit epilepsi sendiri yakni proses patologis yang mendasari terjadinya fokus epileptikus dapat mengganggu secara langsung fungsi otak yang berperan dalam proses terjadinya memori. Aktivitas letupan listrik yang abnormal dari fokus epileptikus juga dapat mengganggu proses pengolahan informasi menjadi memori atau ingatan (Connor, 1994). Faktor lainnya yang berpengaruh terhadap terjadinya gangguan daya ingat adalah lama penggunaan OAE seperti phenobarbital dan fenitoin yang menyebabkan gangguan perhatian dan konsentrasi serta lambatnya pengolahan informasi ke otak (Baker et al., 2008). Pada 40 subjek penelitian ini diketahui lama menderita epilepsi dengan rentang $<1$ tahun sebanyak $12,5 \%$, rentang 1-5 tahun sebanyak $52,5 \%$ dan $>5$ tahun sebanyak 35. Berdasarkan penelitian oleh Baker et al. (2008), diketahui semakin lama menggunakan OAE dapat mempengaruhi daya ingat melalui efek perlambatan pengolahan informasi ke otak.

\section{KESIMPULAN}

Berdasarkan hasil penelitian ini diketahui bahwa ada hubungan atau korelasi positif sedang antara tingkat kepatuhan yang diukur menggunakan kuesioner MGLS dengan kejadian kejang atau Seizure. Tingkat kepatuhan konsumsi obat antiepilepsi pada penelitian ini mayoritas adalah tingkat pa- tuh sedang atau menengah dan persentase kejadian kejang sebulan terakhir sebesar $50 \%$. Ketidakpatuhan konsumsi obat antiepilepsi berdasarkan kuesioner MGLS pada penelitian ini mayoritas terjadi karena lupa minum obat. Diharapkan dapat dilakukan penelitian lanjutan untuk meningkatkan kepatuhan pasien konsumsi obat antiepilepsi untuk mengurangi tingkat lupa minum obat pasien epilepsi.

\section{UCAPAN TERIMA KaSIH}

Ucapan terima kasih ditujukan kepada Rumah Sakit Universitas Airlangga yang menjadi tempat pengambilan data sehingga penelitian ini dapat terselesaikan dengan baik.

\section{Daftar Pustaka}

Al Aqeel S, Al-Sabhan J, Hiligsmann, M. Strategies for improving adherence to antiepileptic drug treatment in people withepilepsy. Cochrane Database of Systematic Reviews. 2017; 2

Al Qarni AM, Al Rahbeni T, Al Qarni A, Al Qarni AM. Adherence to diabetes medication among diabetic patients in the Bisha governorate of Saudi Arabia a crosssectional survey, Patient Preference and Adherence. 2019: vol. 13 63-71

Aminoff A, Douglas V, Nervous System Disorders. In: Papadakis, MA., McPhee, SJ., Rabow, MW. (Eds). Current Medical Diagnosis Treatment 56th ed. New York: McGraw Hill Education. 2017. p 983-990

Baker BA, Hothersal AJ, Mallow JE. Memory. Epilepsy Action. 2008; vol. 10, p16 Beyhaghi H, Reeve BB, Rodgers JE, Stearns SC. Psychometric Properties of the Four-Item Morisky Green Levine Medication Adherence Scale among Atherosclerosis Risk in Communities Study (ARIC) Participants. Value Health 2016; 19 (8): p996-1001

Connor MJ. Epilepsy: Nature, Management, And Memory. Epilepsia. 1994; 24, 1827 Dash D, Sebastian TM, Aggarwal M, Tripathi M. Impact of health education on drug adherence and self-care in people with epilepsy with low education. Epilepsy Behav. 2015; 44:213-217.

Desai JD. Epilepsy and Cognition. J Pediatr Neurosc.2008; 3, 1627 Elger CE, Schmidt D. Modern management of epilepsy: a practical approach. Epilepsy Behav. 2008; vol. 12, p501-39

Ernawati I, Islamiyah, WI. Uji Validitas Dan Reliabilitas Kuesioner Kepatuhan MGLS (Morisky, Green, Levine adherence Scale) Versi Bahasa Indonesia Terhadap Pasien Epilepsi. Jurnal Ilmiah Ibnu Sina. 2019: 4 (2), p305-313

Ernawati, I., Islamiyah, W.R., Sumarno. How to Improve Clinical Outcome of Epileptic Seizure Control Based on medication Adherence? A Literature Review. Open Access Macedonian Journal of Medical Sciences. 2018; 6 (6), p1174-1179.

Farrukh MJ, Bakry MM, Hatah E, Tan HJ. Use of complementary and alternative medicine and adherence to antiepileptic drug therapy among epilepsy patients: a systematic review. Patient Preference and Adherence. 2018 vol. 12, p2111-2121

Ferrari CM, De Sousa RM, Castro LH. Factors associated with treatment non-adherence in patients with epilepsy in Brazil. Seizure. 2013; vol. 22, p384-389 Gabr WM, Shams. Adherence to medication among outpatient ado- 
lescents with epilepsy. Saudi Pharmaceutical Journal. 2105 vol. 23, p33-40

Hovinga CA, Asato MR, Manjunath R, Wheles JW, Phelps SJ, Sheth RD. Association of non-adherence to antiepileptic drugs and seizures, quality of life, and productivity: Survey of patients with epilepsy and physicians. Epilepsy Behav. 2008; 13 (2), p316-322

Islamiyah WR, Suharjono, Jaya HP, Ernawati I, Analysis Relationship of Self-Medication Card Administration with Adherence (ARMS Score), Phenytoin Serum Levels and Frequency of Seizures in Patients using Phenytoin Monotherapy. Research Journal of Pharmacy and Technology. 2019; 12 (12)

Jones RM, Butler JA, Thomas VA, Peveler RC, Prevett M. Adherence to treatment in patients with epilepsy: association with seizure control illness beliefs. Seizure. 2006; vol. 15, p504-8 Leach JP, Davenport RJ, Neurological Disease. In: Walker, BR., Colledge, NR., Ralston, SH., Penman, ID. (Eds). Davidson's Principles and Practice of Medicine 22 th ed. London: Churchill Livingstone Elsevier. 2014. p1137-2230

Leppik IL. Compliance in the treatment of epilepsi. In: The treatment of epilepsi. 2nd ed. Willie E, editor. Williams and Wilkins. 1997. p779-784

Manjunath R, Davis KL, Candrilli SD, Ettinger AB. Association of antiepileptic drug nonadherence with risk of seizure in adults with epilepsy. Epilepsy Behaviour. 2009; vol 14, p372-378 Morisky DE, Green LW, Levine DM. Concurrent and predictive validity of a selfreported measure of medication adherence. Med Care. 1986; vol. 24, p67-74

Novianae L, Sumarno. Ligan SV2A sebagai Terapi Epilepsi. Jurnal Farmasi Udayana. 2020; 9(1):01-12.

O'Rourke G, O' Brien JJ. Review. Identifying the barriers to antiepileptic drug adherence among adults with epilepsy. Seizure.2017; 45

Paschal AM, Hawley SR, Romain TS, Ablah E. Measures of adherence to epilepsy treatment: Review of present practices and recommendations for future directions. Epilepsia. 2008 49(7):1115-22 Rasheva M, Staikov I, Svinarov D, Mihnev N, Neykov N, Staneva M, Low Serum Levels of Antiepileptic Drugs in Patients with Epilepsy-Bad Compliance or Something else. Austin J Clin Neurol. 2015; 2 (10), p1083

Sabaté E. Adherence to long-term therapies: evidence for action. World Health Organization. 2003 Shallcross AJ, Becker AB, Singh A, Friendman D, Jurd R, French JA et al. Psychosocial Factors Associated with Medication Adherence in Ethically and Socioeconomically Diverse Patients with Epilepsy. Epilepsy Behav. 2015.Vol. 46, p242-245.

Suryani NM, Wirasuta IMAG, Susanti NMP. Pengaruh Konseling Obat Dalam Home Care Terhadap Kepatuhan Pasien Diabetes Melitus Tipe 2 Dengan Komplikasi Hipertensi. Jurnal Farmasi Udayana. WHO.World Health Organization Fact Sheet: Epilepsi, updated February. 2017. Available from: http://www.who.int/en/newsroom/fact-sheets/detail/epilepsy

Widyati, Soediatmoko, Ikawati Z, Hakim L, Dampak Positif Pelayanan Farmasi Klinik Pada Pasien Epilepsi. Jurnal Manajemen dan Pelayanan Farmasi. 2013. p217-222
WHO. World Health Organization. Adherence to longterm therapies: evidence for action. Diakses bulan Maret 2020. https://www.who.int/chp/knowledge /publications/adherencereport/en/ 